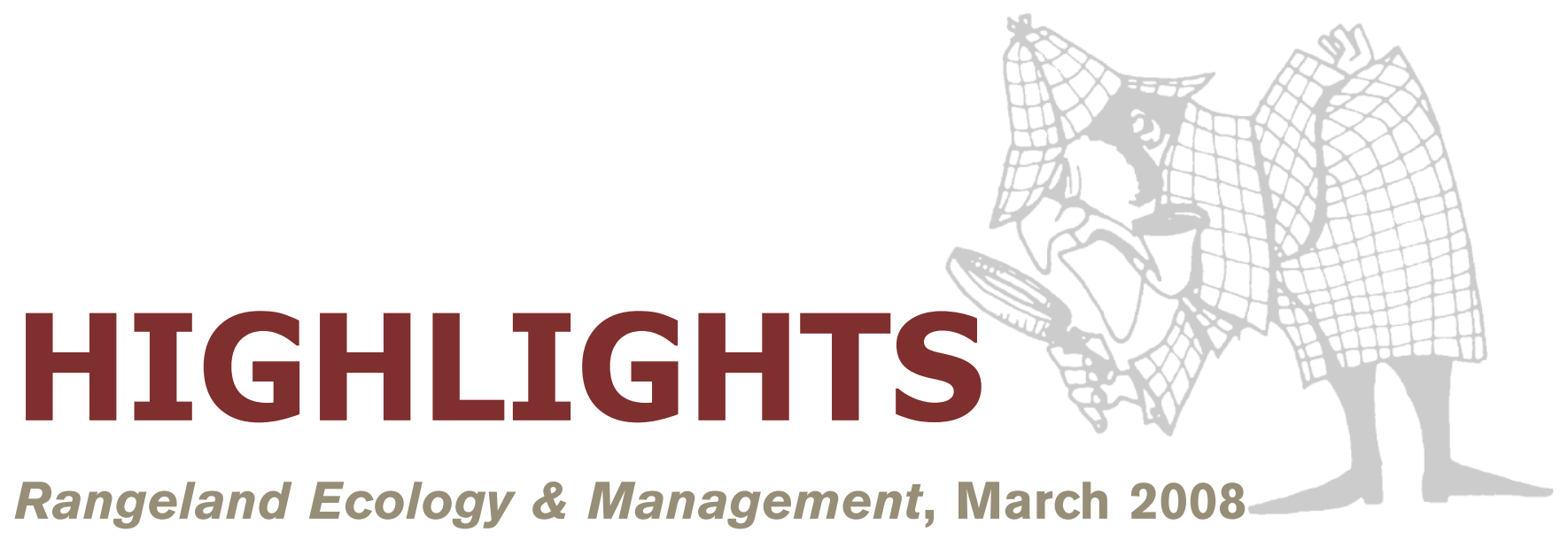

\section{Ranching as a Conservation Strategy: Can Old Ranchers Save the New West?}

Mark W. Brunson and Lynn Huntsinger

It is often argued that preserving working ranches is necessary to sustain the ecological, economic, and cultural aspects of private rangelands. This paper explores those arguments, both to evaluate their basis and also to assess factors that can determine the future of ranching in modern society. Focusing on the western United States, we review research on ranchland conversion, conservation benefits of ranches, and challenges of ranching in modern society. We conclude that there may not be enough traditional ranches and ranchers in the future to meet conservation demand, but traditional ranches along with alternative ownership forms can help achieve those goals.

\section{Knowing the Land: A Review of Local Knowledge Revealed in Ranch Memoirs}

\section{Corrine Noel Knapp and Maria Fernandez-Gimenez}

Rancher knowledge is an untapped source of information regarding rangelands. In this study, we coded and analyzed eighteen ranch memoirs to investigate the specific types, depth, and quality of rancher knowledge. Memoirs revealed that ranchers have an integrated knowledge of management and ecology, gain their knowledge through social interaction, and possess a land ethic that drives their land management. This review provides a framework for future studies of local knowledge by identifying how ranchers gain their knowledge of the landscapes they manage, describing some of the distinctive types of knowledge that ranchers possess, and challenging conventional classifications of rancher knowledge.

\section{Long-Term Effects of a Summer Fire on Desert Grassland Plant Demographics in New Mexico}

\section{Robert R. Parmenter}

Fires may prevent grassland encroachment by shrubs and cholla, and may be useful in restoring grasslands already invaded by woody plants. Fourteen grass, shrub, yucca, and cholla species were examined for 12 years following a summer fire in 1993. Plant species varied in fire-induced mortality and recovery times. The overall fire effect was a reduction in shrubs and cholla, but important grasses (e.g., black grama) exhibited high mortality and slow recovery times. Thus, while fire is clearly a useful tool in range management and restoration, land managers must carefully consider positive and negative species-specific impacts in planning fire management programs.

\section{Prescribed Fire, Soil, and Plants: \\ Burn Effects and Interactions in the Central Great Basin}

\section{Benjamin M. Rau, Jeanne C. Chambers, Robert R. Blank, and Dale W. Johnson}

Land management activities can have impacts on soil nutrients and plant nutrition. We currently do not have a clear understanding of plant and soil interactions in rangeland systems. Our study attempted to identify prescribed fire impacts on plant available soil nutrients and the response of native herbaceous vegetation. We found that burning increased individual plant weight and nitrogen content for most species in our study. This could prove beneficial for native animal species and livestock utilizing these sites.

\section{Response of Acacia sieberiana to Repeated Experimental Burning}

\section{Daniel Aleper, Kåre A. Lye, and Stein R. Moe}

This work investigates whether burning is a devastating or non-devastating factor for the continued conservation of the African tree Acacia sieberiana in Kidepo National Park, Uganda. A burning experiment, using both early and late dry season burning, revealed that two years of consecutive burning increased the number of small trees, although mortality of small trees was also increased by repeated late-season burning. One or two years of burning may be used as a tool to stimulate recruitment of $A$. sieberiana, but additional years of late dry season burning will increase the mortality of older trees. 
The Response of Thurber's Needlegrass to Fall Prescribed Burning

\section{Kirk W. Davies and Jonathan D. Bates}

The response of Thurber's needlegrass (Achnatherum thurberianum [Piper] Barkworth) to prescribed fall burning is largely unexplored. Thurber's needlegrass cover, density, biomass production, photosynthetic rates, tissue carbon (C) and nitrogen $(\mathrm{N})$ content, and $\mathrm{N}\left({ }^{15} \mathrm{~N} /{ }^{14} \mathrm{~N}\right)$ and $\mathrm{C}\left({ }^{13} \mathrm{C} /{ }^{12} \mathrm{C}\right)$ isotope ratios were compared between prescribed fall burned and unburned Wyoming big sagebrush (Artemisia tridentata subsp. wyomingensis [Beetle \& A. Young] S. L. Welsh)bunchgrass communities. Thurber's needlegrass density and cover generally did not differ between treatments. Nitrogen isotope ratios and photosynthetic rates suggested more resources were available to Thurber's needlegrass in the burned than unburned treatment. However, $\mathrm{C}$ isotope ratios suggested that water was less available in the burned than unburned treatment in the first post-burn year. Our results suggest prescribed fall burning is not detrimental to Thurber's needlegrass and can be used to shift dominance from sagebrush to herbaceous vegetation.

\section{Grazing Impacts in Vegetated Dune Fields: Predictions From Spatial Pattern Analysis}

Paula D. Blanco, César M. Rostagno, Héctor F. del Valle, Ana M. Beeskow, and Thorsten Wiegand

This study addresses grazing-induced changes on soil erosion processes in vegetated dunefields of Patagonia. Blowouts, used as erosion proxies, were mapped on aerial photographs and Landsat images, in paddocks under different grazing intensities. We calculated a spatial statistic (O-ring) that gives the expected intensity of blowouts within the area covered by dune crests as a function of distance away from waterpoints. Significant blowout aggregations around waterpoints were found at heavily grazed paddocks with high dune crest densities. The location of waterpoints in sites less susceptible to accelerated soil erosion would improve management strategies for the dunefields of Península Valdés.

\section{Grazing Systems for Yearling Cattle on Tallgrass Prairie}

Clenton E. Owensby, Lisa M. Auen, Hannah F. Berns, and Kevin C. Dhuyvetter

Late-season forage quality was enhanced by stocking at twice the season-long, moderate stocking rate for the first half of the growing season and at the moderate rate for the latter half (IES/LSG). During the 9-year study, the IES+ System was composed of IES/LSG, stocking at twice the normal rate for the first half of the growing season (IES) and season long at a moderate rate during consecutive years. IES+ was compared to SLS and IES repeatedly applied.
Marketing diversity and net profit were enhanced and risk reduced using IES+ compared to repeated IES or SLS.

\section{Crested Wheatgrass Defoliation Intensity and Season on Medusahead Invasion}

Roger L. Sheley, Brett S. Bingham, and Tony J. Svejcar

Understanding how grazing affects plant invasion is critical to implementing prevention programs. We defoliated crested wheatgrass from $0 \%$ to $100 \%$ in the spring or fall at two sites with soils varying in clay content. We seeded each area with medusahead. On high clay soils, medusahead established well, but was less dense where defoliation occurred after the growing season. Medusahead established poorly on less clayey soils. At term, medusahead was absent where crested wheatgrass was moderately defoliated. This suggests that grazing can accelerate invasion by medushead, but proper grazing may keep the grass competitive on good quality sites.

\section{Conifer Dispersion on Subalpine Pastures in Northeastern Spain: Characteristics and Implications for Rangeland Management}

\section{Jordi Bartolomé, Martí Boada, David Saurí, Sònia Sánchez, and Josefina Plaixats}

This paper examines conifer invasion in pastures of the Mediterranean mountains. Pinus sylvestris and P. mugo, originating from plantations established during the 1960s, are invading subalpine heathlands in Montseny Natural Park (NE Spain). P. sylvestris is the most successful invading species. This invasion appears to be stimulated by a combination of natural and human factors, including differences between vegetation components, climate, change in land use, creation of plantations, and probably the nurse role played by accompanying dwarf shrubs.

\section{GPS Collar Sampling Frequency: Effects on Measures of Resource Use}

\section{Dustin D. Johnson and David C. Ganskopp}

Despite recent electronic advancements, GPS collar users are challenged with selecting sampling regimes and deployment durations that satisfy research needs, but do not exceed instrument memory or battery capacity. We iteratively sub-sampled 5-min GPS collar data to mimic sampling regimes from a 10-min interval to once daily and quantified effects on measures of pasture use and distance traveled by cattle. Expanded sampling intervals decreased estimates of pasture use and travel with 3-parameter exponential decay functions best fitting rates of decline. Findings will help GPS collar users select sampling regimes that best meet their research needs. 


\section{Predicting Diet Quality of Donkeys via Fecal-NIRS Calibrations}

Negusse F. Kidane, Jerry W. Stuth, and Douglas R. Tolleson

Near infrared reflectance spectroscopy (NIRS) has been recently introduced as a tool to predict the protein and digestibility of forages consumed by ruminant animals. The potential of this technique has not been tested in equines. We calibrated and validated first generation fecal NIRS equations to predict the $\mathrm{CP}$ and DOM of diets for donkeys. Results have shown the accuracy obtained for CP was equivalent to that of wet chemistry methods, while prediction of DOM was less successful. Thus, we believe that fecal-NIRS equations developed here can be considered as a potential tool not only to determine the nutritional wellbeing of free-grazing donkeys in a very cost effective manner, but also as a tool to judiciously manage rangeland resources.

\section{Effects of Experience and Lactation on Lupine Consumption by Cattle}

\section{James A. Pfister, Stephen T. Lee, Kip E. Panter, Ernie S. Motteram, and Clive C. Gay}

Lupines are widespread range plants that are often toxic to livestock and cause deformities in newborn calves. The objective of this study was to examine the influence of experience and lactation on lupine (Lupinus leucophyllus
Dougl.) intake by grazing cattle in eastern Washington state. We found no difference in consumption of lupine by naive and experienced cows, nor did we find differences between lactating and dry cows. Our results suggest that experience and lactation status are probably minor considerations in livestock management schemes to reduce losses to lupine.

\section{Classification of Digital Photography for Measuring Productive Ground Cover}

\section{J. D. Rotz, A. O. Abaye, R. H. Wynne, E. B. Rayburn, G. Scaglia, and R. D. Phillips}

Productive ground cover (PGC) was measured by constructing a camera stand to provide diffuse lighting of grass swards for color digital photography. Photographs were classified into productive and nonproductive cover using Mahalanobis distance. Productive ground cover techniques were tested on a grazing experiment that used four forage types. The accuracy of the PGC maps was assessed using a stratified subsample of 48 images, 12 from each of four productive cover classes. PGC percentages had an $83.7 \%$ agreement with the PGC maps. However, the percentages derived from the PGC maps were not well-correlated with the PGC percentages derived from either ocular estimation $(r=0.22)$ or a simple digital point quadrat method $(r=0.47)$. This experiment highlights the potential for semi-automated classification of ground-based digital photographs for estimating PGC. 